\title{
A TEST OF AN EFFICIENCY MODEL OF GRIEVANCE ACTIVITY
}

\author{
PETER GAPPELLI and KEITH CHAUVIN*
}

\begin{abstract}
The authors develop a model in which the extent of use of a grievance system is determined by wage premiums and alternative job opportunities. Specifically, they hypothesize that when workers enjoy comparatively high wages or are faced with poor alternative job opportunities, they are less likely to use withdrawal mechanisms that might lead to dismissal (such as shirking or absenteeism) and more likely to use grievance procedures to address workplace problems. The results of an analysis of data for the year 1982 from a large manufacturing company are consistent with this hypothesis.
\end{abstract}

$\mathrm{E}$ MPLOYEE grievances are one of the most common measures used to evaluate the level of conflict between workers and management and the overall state of employee relations. There has been little conclusive research on the causes of grievances, however, and none of the published studies on the subject consider the role that factors outside the organization, such as labor market conditions, might play in determining the rate of grievances. In this paper we develop a simple model in which the extent of use of the grievance system to resolve conflicts is determined by wage premiums and alternative job opportunities. The model is tested using data for 1982 taken from a large multiplant manufacturing company.

\footnotetext{
* Peter Cappelli is Associate Professor of Management and Co-Director of the Center for Human Resources at the Wharton School, University of Pennsylvania, and Keith Chauvin is Assistant Professor at the School of Business, University of Kansas. The first author thanks the German Marshall Fund for financial support for this research. The authors also thank Bruce Fallick, David Lewin, and Michael Wachter for helpful comments. The company providing the information for this study prohibits the release of the data. Other scholars may analyze the data using the authors' computer system in order to reproduce the results presented here.
}

\section{Previous Research on Grievances}

Grievances are charges by employees that their rights have been violated by management actions or decisions. In most cases, the rights in question have been established by collective bargaining agreements, although they may also be rights established by company policies or by precedent. (See Lewin and Peterson 1988, Chap. 2 for a review of the literature on grievance procedures.) The rate at which grievances are filed by employees is an important measure of the state of employee relations because it is indicative of the underlying level of conflict between workers and management and of the morale of the work force, factors that can affect performance. There is evidence, for example, that plants with higher grievance rates have lower productivity (Norsworthy and Zabala 1985; Ichniowski 1986) and lower levels of output quality (Katz, Kochan, and Gobeille 1983) because they have more workplace conflicts and problems. ${ }^{1}$ This is

\footnotetext{
${ }^{1}$ Kleiner, Nickelsburg, and Pilarski (1989) found a more complicated, non-linear relationship between grievances and productivity, and Katz, Kochan, and Gobeille (1988) found no statistically significant relationship between the two.
} 
not to suggest that the grievances per se are the cause of lower productivity. Rather, the argument is that they are a proxy for problems, not all of which can be resolved completely through the grievance process. The unresolved problems can have a range of negative effects on employee behavior, as we discuss below.

Attempts to explain the determinants of grievance rates have focused almost exclusively on factors of traditional interest to industrial psychologists, such as the characteristics of workers who are likely to file grievances. These studies have focused on individual attributes such as demographic characteristics and personality traits. As one review notes, however, this literature has produced no clear pattern of results; the only consistent finding across studies is that younger workers file more grievances than older workers (Murchinsky and Maassarani 1980). Other attempts have looked at the structure of the organization as a determinant of grievance rates, but here too the results conflict (see Gordon and Miller 1984). Nor do the characteristics of the jobs (Ash 1970) or the style and characteristics of leadership-either management or union-play a consistent role in explaining grievance rates (Lewin 1983). Indeed, it is not even clear from previous research whether grievance rates are higher in union than in nonunion workplaces (for example, Kissler 1977). ${ }^{2}$

In short, the existing literature offers a sometimes conflicting and at best incomplete explanation of grievance rates. Certainly one characteristic of this literature,

\footnotetext{
${ }^{2}$ It might seem apparent that the characteristics of unions and especially of their shop stewards are an important factor, since, among other things, shop stewards counsel the grievant initially about the likelihood that a grievance will be sustained and, therefore, about whether it should be filed at all (Dalton and Todor 1979). However, recent developments that have made it easier for workers to successfully sue their union for failing to represent them adequately in grievances cases (the so-called "duty of fair representation") have made unions very reluctant to dissuade a member from filing a grievance (see McKelvey 1977). Kleiner, Nickelsburg, and Pilarski (1989) did find, however, that unionrelated events such as strikes and union elections affect grievance activity.
}

as of behavioral research in general, is that it has looked only at factors within the firm (see Cappelli and Sherer 1990); in particular, no study has investigated the general role that market forces or economic circumstances might play in shaping the grievance rate. ${ }^{3} \mathrm{~A}$ more general model of grievances based on a consideration of factors external to the firm is presented below.

\section{The Decision to File a Grievance}

The first point of departure from the previous literature is to note that the decision to file a grievance involves a consideration of the alternative methods for dealing with the perceived inequity or conflict that occurs when management is seen as violating a worker's rights. There is an extensive body of research in psychology indicating that when employees perceive inequity that cannot be rationalized away, they try to reestablish a sense of equity either by withdrawing from the situation (for example, via absenteeism or quitting) or by reducing their effort and inputs to the job, what economists generally describe as shirking. This argument is generally known as "equity theory," and wide-ranging studies in organizational psychology over the past two decades have found considerable support for it (see Adams 1963 for a description, and Berkowitz and Walster 1976 and Weick 1979 for surveys of its applications).

The mechanisms of withdrawal and reducing inputs can be exercised unilaterally and can provide more or less immediate satisfaction, two potential advantages from the worker's perspective. They clearly impose costs on the employer, however, and may lead to costs for the employee as well, costs that we examine below. The procedural arrangements as-

\footnotetext{
${ }^{3}$ One possible exception is Peach and Livernash's 1974 case study of grievance rates in basic steel. They considered the indirect relationship between tight labor markets and turnover that, in turn, led to more frequent selection and placement decisions and to additional grievances.
} 
sociated with union representation, as Freeman (1980) has argued, add further mechanisms for dealing with the problems of individual employees. The most important of these "voice" mechanisms for addressing the workplace problems of workers as individuals is clearly grievance procedures, although in some cases unauthorized industrial action by a group of workers (wildcat strikes) can also be a means of forcing a resolution of these problems. And although collective bargaining is in general an important voice mechanism, it typically focuses on issues of concern to the work force as a whole rather than on the kind of individual-level inequities that lead to most grievances.

The employee's decision to address a problem through grievance procedures should involve some comparison of the cost and effectiveness of the various methods for dealing with workplace problems. Although grievants are protected from reprisals by management, and the administrative costs of presenting the grievance are borne by the union, ${ }^{4}$ there may be important psychological costs in the form of confronting one's supervisors, being cross-examined as part of the proceedings, waiting months or longer for the grievance to be resolved, and so on. These costs may vary across individuals, but they may reasonably be thought of as fixed for the kind of intra-firm, plant-level comparisons considered below, not only because the grievance process is the same for all workers but also because the kind of plant-level aggregated information we will use tends to cancel out individual-level differences.

The costs of using alternative methods of problem-solving, however, clearly are not fixed. For example, where workers receive a wage premium over alternative jobs in the outside market, they have a greater incentive to deal with work-related problems through grievance procedures, because the alternative mechanisms might lead to a loss of that premium. Quitting clearly does so;

\footnotetext{
${ }^{4}$ The exception is the railroad industry, in which the costs of the grievance system are heavily subsidized by the government.
}

absenteeism and other forms of shirking increase the probability of dismissal; and strikes lead not only to a loss of wages but also to the possibility of losing one's job to permanent replacements or, in the case of unauthorized wildcat strikes, by dismissal.

It is important to note the distinction between this position and Freeman's (1980) voice argument. Freeman argued that the availability of voice mechanisms like grievance procedures leads to changes in employee behavior (for example, longer tenure and lower turnover). We argue that use of the "voice" mechanism is itself an outcome: the extent to which employees want to use grievance procedures is a function of the costs of using alternative mechanisms, costs shaped by the value of one's current job relative to opportunities elsewhere, which in turn varies with conditions in the labor market. Hirschman (1970, Chap. 3) drew a similar distinction between situations in which voice is an alternative to exit and those in which voice mechanisms are used because exit is not a viable alternative. Freeman's argument corresponds to the former situation, whereas ours is closer to the latter. ${ }^{5}$

There is evidence from other studies to support the general view that the use of grievance procedures is a function of the costs and effectiveness of alternative methods for dealing with worker problems. Kuhn's (1961, Chap. 5) case study of workplace relations in the tire industry, for example, illustrates how slowdowns and wildcat strikes replaced the formal grievance process as a means for addressing workplace conflicts. As the bargaining power of the work groups increased, the cost of using the former methods fell. At least one experimental study suggests that grievance procedures are used less and turnover and strikes are higher when the grievance process is perceived as being more costly to use-slow-moving, inequitable, and operating poorly (Sulkin and

\footnotetext{
${ }^{5}$ Akerlof (1982:550) offered in passing a somewhat similar argument, namely, that unions-and presumably the voice mechanisms associated with them-are more likely to form where jobs offer some premium over opportunities elsewhere, because the alternative of quitting is less attractive in such jobs.
} 
Pranis 1967). Ichniowski (1986) found that in the absence of a grievance procedure, productivity is lower, which we would explain as reflecting workers' use of less constructive means for dealing with problems, such as shirking or quitting.

The argument that a wage premium may have the effect of increasing the use of grievance procedures is related to the general efficiency wage hypothesis in economics, which argues that a wage premium may change employee behavior in ways that benefit the firm. ${ }^{6}$ Management should prefer that conflicts be addressed through the grievance procedure rather than through the more costly alternatives noted above, and a wage premium makes the routine use of a grievance procedure more likely. Indeed, this explanation of grievance use is in fact a corollary of efficiency wage theories, which suggest that wage premiums raise the cost of shirking (for example, Shapiro and Stiglitz 1984) and of turnover (for example, Krueger and Summers 1987), two important alternatives for dealing with conflicts, by raising the costs of losing one's job. In other words, the wage premium lowers the relative cost of using the grievance system by raising the costs associated with alternative methods. ${ }^{7}$

\section{Model and Data}

From the perspective of workers, their use of the grievance procedure can be thought of as a simple optimization problem whereby they minimize the costs of resolving their perceived problems by choosing among alternative resolution mechanisms, subject to a given level of perceived conflicts and problems. Conditions in the labor market determine the costs of using alternative mechanisms. Specifically, we hypothesize that the use of

\footnotetext{
${ }^{6}$ See Akerlof and Yellen (1986) and Stiglitz (1986) for surveys of the efficiency wage literature.

${ }^{7}$ It is important to remember, however, that because workers cannot be disciplined or dismissed for filing grievances, the threat of losing that premium should not lead to a reduction in grievances.
}

grievance procedures varies directly with the size of the wage premiums and with the level of unemployment in the outside labor market. (A formal version of this model is outlined in the appendix.) We propose to test the argument outlined above with an interesting set of plant-level, employee-relations data taken from a large manufacturing company. The characteristics of these data help to control for many of the experimental and statistical problems that could confound tests of a relationship between grievance activity and economic circumstances.

Perhaps the most important problem is the need to control for underlying levels of conflict and perceived inequity across plants. Grievance activity might be higher because a plant has more problems as well as because labor market circumstances at that plant make it more desirable to use the grievance process for addressing those problems. Fortunately, the design of our data can control for many of the factors that previous research suggests might influence the underlying level of conflict across plants. For example, the plants in our study are all engaged in the same basic type of manufacturing, and we can also identify categories of plants within the firm by their function - either assembly or components (parts) manufacturing-in the overall production process. The nature of production work is largely the same across plants with similar functions. As a result, there are few systematic differences in job characteristics across such plants.

Second, because the plants are all within the same company and are represented by the same union, there are no basic differences in management and union policies of the kind that may affect levels of conflict and grievance rates in interfirm studies. Further, all of the plants are covered by the same union contract, which specifies procedures for dealing with grievances. The contract also establishes virtually identical terms and conditions of employment across plants. Finally, a company-wide union-management committee reviews all grievances that are not settled at the plant level and attempts to apply 
consistent solutions to such cases. This structure helps standardize practices with respect to grievances across plants and, more important, helps standardize employment practices across plants.

The design of the data also helps ensure that the direction of causation is clear: because compensation is determined centrally through collective bargaining and is identical across plants, we know that differences in grievances and in related aspects of employee relations cannot be causing differences in relative compensation across plants.

The variables used in the study are reported in Table 1 and are described below.

Wage premium. Although wage rates are identical across plants, the extent of the wage premium above the market level varies across plants. The plants in this company are distributed widely across the United States and therefore operate across very different labor markets where rates of pay for production jobs vary considerably. The wage premium (WPREM), measured as the difference between the average hourly wage of workers in the plant and gross average hourly wages prevailing in the plant's Standard Metropolitan Statistical Area (SMSA) for production work, varies from almost zero to as much as $100 \%$. (Four plants were located outside of SMSAs, and the appropriate state-wide gross average hourly wage was used in those cases.) Larger premiums increase the cost of using the alternative mechanisms for dealing with conflict noted above. We recognize that this aggregate measure will not accurately capture the labor market alternatives for all plant workers. The measurement error that results makes it more difficult to find significant relationships with grievancesmaking for more conservative tests of hypotheses-but also may bias the estimator.

Plant type. There are several reasons for believing that workers in assembly plants should make greater use of grievance procedures. First, because assembly work is often thought to be more machinepaced and oppressive than the work in the other (parts-manufacturing) plants, workers in assembly plants may experience a higher level of underlying conflict, leading in turn to higher grievance levels (Blauner 1964). Further, the wage premium as

Table 1. Variable Definitions and Mean Values.

\begin{tabular}{|c|c|c|c|}
\hline Variable & Definition & Mean & S.D. \\
\hline GRIEV & $\begin{array}{l}\text { Grievances divided by average number of workers in plant's } \\
\text { bargaining unit (1st written step grievances) }\end{array}$ & 22 & 15.1 \\
\hline WPREM & $\begin{array}{l}\text { Plant wage (average hourly wage for plant workers) minus gross } \\
\text { average hourly wage for production workers in the SMSA where } \\
\text { the plant is located }\end{array}$ & $\$ 3.02$ & 1.5 \\
\hline UE & Unemployment rate in the SMSA in which the plant is located ${ }^{a}$ & 12.84 & 4.0 \\
\hline LAIDOFF & Percentage of workers in bargaining unit on layoff & 25.71 & 16.5 \\
\hline COOP & $\begin{array}{l}\text { Corporate assessment of cooperative relations/problem-solving at } \\
\text { plant }(1=\text { most cooperative; } 7=\text { least })\end{array}$ & 3.52 & 0.8 \\
\hline ASSMBLY & Dummy variable for assembly plants & 0.28 & 0.45 \\
\hline SEN & $\begin{array}{l}\text { Percentage of workers in bargaining unit with less than ten years } \\
\text { of seniority }\end{array}$ & 45.2 & 19.3 \\
\hline SKL & Percentage of workers in bargaining unit with craft jobs & 18.06 & 9.9 \\
\hline DISL & $\begin{array}{l}\text { Number of workers dismissed for disciplinary reasons divided by } \\
\text { number of workers in bargaining unit }\end{array}$ & 9.68 & 6.2 \\
\hline ABST & $\begin{array}{l}\text { Average monthly unpaid absences divided by number of workers } \\
\text { in the plant's bargaining unit }\end{array}$ & 6.0 & 4.1 \\
\hline GRATE & GRIEV/DISL + ABST + GRIEV (all observations $>0,<1$ ) & 0.23 & 0.18 \\
\hline
\end{tabular}


measured above may understate the true premium for jobs in assembly plants. Assembly work may require less skill than many jobs in component manufacturing (where machining and other semi-skilled work is more common), and the workers in assembly jobs should therefore command a somewhat lower wage on the outside market. Because the measure of wages for production work in the outside labor market does not differentiate between assembly and component work, the real wage premium for assembly plant jobs may be higher than the measure used here. Workers in these plants appear to have more to lose if dismissed and should therefore be more inclined to use the grievance procedure and less inclined to pursue alternative mechanisms associated with job loss than our wage premium measure would suggest. A variable is included to distinguish assembly plants from plants involved in less automated, component manufacturing (ASSMBLY).

Unemployment. In addition to the wage premium, we include a measure of the percentage of workers on layoff at each plant (LAIDOFF) as well as the unemployment rate in each plant's SMSA (UE). The former can be thought of as the rate of unemployment for workers at each plant. Both measures suggest something about the opportunities for alternative employment; where unemployment rates are high, it is more difficult (costly) to find a new job if one quits or is dismissed for shirking. Similarly, it may be more difficult to find a job where more of one's fellow workers (whose skills and job searches are likely to be similar) are laid off. Therefore, use of the grievance system should vary directly with these rates.

These variables all serve as proxies for the cost of alternative methods for resolving conflicts, and the model described above suggests that they should all be positively related to grievance rates. We also include other variables to control for forces exogenous to the model that might influence the level of grievances by increasing the level of perceived conflict and problems across plants.
Seniority. There are at least two conflicting hypotheses concerning the relationship between seniority and grievance use. As noted above, previous studies suggest that younger employees and employees with less experience tend to perceive less equity, have more complaints, and file more grievances. The reason may be, as Borjas (1979) suggested, because they have had less time in which to make a good job match and are therefore less likely to be satisfied with the job they currently hold than are older and more experienced workers. On the other hand, the costs of job loss associated with using nongrievance mechanisms are greater for older workers with more seniority, because it may be more difficult for them to find alternative jobs, and they may lose seniority-based entitlements such as pension rights. We might therefore expect them to make greater use of the grievance process to resolve whatever inequities they do perceive. We include a measure of average company seniority (SEN) across plants as a measure of job experience and as a rough proxy for average worker age, but the sign of the relationship with grievance activity is difficult to predict.

Craft status. There may be some differences across plants in the average characteristics of jobs and of workers in them, due not only to the plant type but also to differences in the proportion of workers doing traditional craft work (such as electricians and plumbers). Craft workers are present in every plant, where they typically perform maintenance functions, but their presence across plants varies, for example, because of differences in the age and state of the capital equipment. The jobs of craft workers differ from those of non-craft production workers, and the characteristics of craft workers may be different as well, since these workers come from skilled labor markets that exist independently of the firm.

It is not clear a priori or from previous research, however, exactly what influence the presence of skilled workers might have on average grievance rates. One former union official in the industry suggested to us that workers in skilled trades have more 
complaints because their jobs are less defined-possibly raising grievance levels-but also are more able to get them addressed informally, outside of the grievance process, because of their greater individual bargaining power-possibly lowering grievances. Further, workers with craft skills may have better job alternatives than other workers and be less reluctant to use methods of solving problems other than the grievance system. Like seniority, therefore, the skill variable may also capture some aspect of job alternatives. We include a variable for the percentage of workers with skilled trades jobs in each plant (SKL) to capture these effects.

Cooperation. The final variable (COOP) attempts to control for differences in the level of conflict across plants and in the ability to solve problems that arise informally before they are filed as grievances. Officials from the company's corporate staff assessed each plant according to how well plant management and the local union worked together. Plants in which management and local union officials had good problem-solving skills and used them to solve problems jointly (as opposed to plants in which problems were addressed through confrontation) were rated as cooperative. (Management officials stated that this measure was not based on plant grievance rates.) The general ability of unions and management to work well together may reduce the number of conflicts that affect individuals and may help to resolve problems informally. Greater cooperation should therefore be associated with lower levels of conflict and grievances.

Ideally, such measures should be defined in terms of actual behaviors exhibited by the parties, and the more behaviors the better. As is often the case, however, this measure was more impressionistic, based on the question, "How cooperative are plant-level labor relations?" and assessed on a 1-7 point scale with $1=$ most cooperative. The corporate staff looked for the presence of joint union-management programs, evidence of cooperative approaches to solving specific problems, and attitudes expressed by union and plant management officials toward each other as indications of the extent of cooperative relations at each plant.

Obviously, there may be differences in underlying levels of conflict across plants that are not captured by the control variables above. But for the purposes of the test of the model proposed here, the issue is whether unexplained differences in levels of conflict across plants are positively correlated with the labor market variables, a relationship that would confound the test.

If there is any relationship between levels of conflict and labor market conditions as measured by the right-hand-side variables, it is likely to be an inverse relationship and to work against our hypothesis. Workers' judgments as to the equity of particular management actions that might lead to grievances are not made in a vacuum, but presumably are based in part on their overall sense of equity and satisfaction with the other aspects of their jobs. One way to think of this argument is as an application of compensating differentials; if workers feel generally satisfied with the other aspects of their jobs, they may be less likely to perceive inequities in particular management decisions and, in turn, less likely to file grievances. Previous research lends support to this position. For example, the size of the wage premium above market rates is positively associated with aspects of job satisfaction (Cappelli and Sherer 1988), and higher unemployment rates in the external labor market are also associated with higher levels of satisfaction for those with jobs (Smith, Kendall, and Hulin 1969). Where levels of satisfaction are higher, one would expect perceived inequities and conflict to be lower, ceteris paribus, and grievances to be lower as well. Further, higher wage premiums and tighter labor markets may allow plant management to hire betterquality workers. As Staw, Bell, and Clausen (1986) found, some workers are disposed toward lower job satisfaction and greater complaints independent of their jobs, and management may be able to use tighter labor markets to hire fewer of such 
workers. ${ }^{8}$ Therefore, higher wage premiums and greater unemployment should be associated with lower levels of underlying conflict and should, if anything, operate against the relationship suggested by the model, making for a more conservative test of our hypothesis.

The specification of the model is straightforward. The measure for grievance rates (GRIEV) is the number of written first-step grievances as a proportion of the average number of workers during 1982 in each plant's bargaining unit. The rate varies between 0 and 1 , and therefore a log-odds ratio of the variable is used in the estimating equation. Because the dependent variable and several of the independent väriables are plant-wide averages based on the characteristics of all employees at each plant, the estimates for plants with fewer employees will have more error. Weighted least squares is used to correct for the heteroscedasticity that results. And as Amemiya and Nold (1975) pointed out, the weights should include a correction for equation error to prevent understating the standard errors of the estimates. 9 The estimating equation is as follows:

\footnotetext{
${ }^{8}$ There may, however, be exceptions to this argument. Greater unemployment in the outside labor market and higher plant wage premiums may also give management more freedom to tighten discipline and to discharge more employees because the supply of replacements, and presumably their quality, is greater. Tighter standards may lead to more grievances. But centralized company personnel policies and common grievance standards limit the ability of plant management to take such actions. Further, it is not at all obvious that stricter standards-if they do occur-would be enough to overcome the above relationships and lead to a net increase in grievances. Second, unions may file more grievances in response to at least certain kinds of layoffs in an attempt either to reverse the layoffs or simply to protest them. Where this is the case, there may be some positive association between the LAIDOFF variable and grievance levels.

${ }^{9}$ Each observation was weighted by $\left[s_{\text {ols }}^{2}+\right.$ :EMPLOYMENT $_{k} *$ Grievances $_{k}\left(1-\right.$ Grievances $\left.\left._{k}\right)\right\}^{1(1 / 2)}$, where $s_{\text {ols }}^{2}$ is an estimate of the variance calculated from the parameters of an OLS estimation of the above $\log$ odds equation and EMPLOYMENT EN $_{k}$ is the number of workers at each of $k$ plants. The log odds equation was then estimated again using the weighted observations.
}

(1) $\ln ($ GRIEV/ $1-$ GRIEV $)=$ $a+b_{1}$ WPREM $+b_{2}$ ASSMBLY $+b_{3}$ LAIDOFF
$+b_{4} \mathrm{UE}+b_{5}$ SEN $\pm b_{6}$ SKL $-b_{7} \mathrm{COOP}+e$

We can use additional data to further control for the possibility that underlying levels of conflict differ across plants. The ideal measure would be one that included all the worker conflicts and problems at the plant that could have gone through the grievance process-not only those dealt with through the grievance system but also those handled through the alternative channels described above. With such a measure it would be possible to identify the plants in which the grievance process handled a larger percentage of the total workplace problems.

Not surprisingly, no such direct measure exists, but it is possible for us to construct a rough proxy for it by examining the other mechanisms for addressing a sense of grievance outlined above. We have a direct measure for one of the alternative mechanisms: unpaid (unexcused) absenteeism, expressed as the average number of unpaid days absent divided by the number of workers in the bargaining unit. (This measure is sometimes referred to as "controllable absenteeism.") We also have a direct measure for withdrawal of effort associated with shirking. That measure is the rate of disciplinary layoffs, expressed as the number of such layoffs divided by the number of workers in the bargaining unit. The collective bargaining agreement restricts use of this disciplinary action to issues associated with shirking, broadly defined (for example, failure to meet production standards, failure to follow instructions, carelessness, and safety violations).

One important withdrawal mechanism for which we have no direct measure is voluntary turnover. The year in which the data for this study were collected, however, was a recession year (1982), and voluntary turnover at that time, according to managers, was virtually nonexistent, since the unionized jobs provided by this company were better than alternative jobs in the communities where the plants were located. Also, evidence from other studies suggests that 
turnover and absenteeism tend to be correlated in cross-sectional data (Porter and Steers 1973; Mobley 1979), so some of the variance in turnover may be captured by the absenteeism variable.

One problem is that these measures might include absences and shirking that arise not only from the kind of complaints against management that could result in grievances but also from other kinds of problems that cannot be handled through the formal grievance procedure, such as personal difficulties that are not caused by the job. There is, however, no a priori reason to believe that the proportion of nongrievable problems represented by these variables should vary systematically across plants and bias the results.

Each of the grievance, absenteeism, and discipline variables identifies individual incidents that could be manifestations of a sense of inequity, and all are expressed as the rate per 100 workers. They were therefore combined into an index with equal weights. Grievance rates are then expressed as a percentage of that index (see Table 1). The variable that results (GRATE) can be thought of as a rough proxy for the percentage of potentially grievable workplace problems that were actually addressed through the grievance procedure. ${ }^{10}$ This variable is bounded between 0 and 1 and is therefore expressed in the form of a log-odds ratio $[\ln (\mathrm{GRATE}) / 1-$ GRATE $)]$. This variable is then regressed on the same set of independent variables used above:

(2) $\ln$ (GRATE/ 1 - GRATE $)=a+b_{1}$ WPREM

$$
\begin{aligned}
& +b_{2} \mathrm{ASSMBLY}+b_{3} \mathrm{LAIDOFF} \\
& +b_{4} \mathrm{UE}+b_{5} \mathrm{SEN} \pm b_{6} \mathrm{SKL}-b_{7} \mathrm{COOP}+e
\end{aligned}
$$

${ }^{10}$ No doubt there is covariance among grievances, absenteeism, and disciplinary actions-for example, many disciplinary actions will be grieved-and therefore the inclusion of absence and discipline adds less information than one might have hoped for. But it is also clear that these three measures are far from identical and that some information is therefore gained as a result of including all of them.

There were no shop floor or wildcat strikes, an alternative method for dealing with problems that extend to groups, during the period considered here.

\section{Results}

The results are presented in Table 2. Beginning with equation (1), the wage premium (WPREM) is positively and significantly related to grievance rates, suggesting that the use of grievance procedures does increase as the wage premium rises because the costs of using alternative methods for conflict resolution rise. Similarly, plant-level unemployment (LAIDOFF)

Table 2. Effects of Wage Premiums and Alternative Job Opportunities on Grievance Rates in a Manufacturing Firm, 1982:

Regression Results for Log-Odds Grievance Measures Across Plants.

\begin{tabular}{|c|c|c|}
\hline Dependent Variable & $\begin{array}{c}\text { Equation } 1 \\
\text { GRIEV }\end{array}$ & $\begin{array}{c}\text { Equation } 2 \\
\text { GRATE } \\
\end{array}$ \\
\hline Intercept & $\begin{array}{c}-4.37 * * * \\
(4.60)\end{array}$ & $\begin{array}{c}-0.275^{* * *} \\
(1.64)\end{array}$ \\
\hline WPREM & $\begin{array}{l}0.46^{* * * *} \\
(4.37)\end{array}$ & $\begin{array}{l}0.069 * * * \\
(3.68)\end{array}$ \\
\hline UE & $\begin{array}{l}0.10^{* * * *} \\
(2.64)\end{array}$ & $\begin{array}{l}0.014^{* * *} \\
(2.08)\end{array}$ \\
\hline LAIDOFF & $\begin{array}{l}0.008^{*} \\
(1.65)\end{array}$ & $\begin{array}{l}0.008^{*} \\
(1.90)\end{array}$ \\
\hline COOP & $\begin{array}{c}-0.13 \\
(1.21)\end{array}$ & $\begin{array}{c}-0.0056 \\
(0.28)\end{array}$ \\
\hline ASSMBLY & $\begin{array}{l}0.56 * * \\
(2.40)\end{array}$ & $\begin{array}{l}0.096 * * \\
(2.36)\end{array}$ \\
\hline SEN & $\begin{array}{c}0.008 \\
(1.52)\end{array}$ & $\begin{array}{l}0.0014 \\
(1.55)\end{array}$ \\
\hline SKL & $\begin{array}{c}0.014 \\
(1.25)\end{array}$ & $\begin{array}{l}0.0023 \\
(1.16)\end{array}$ \\
\hline $\mathrm{R}^{2}=$ & .46 & .41 \\
\hline $\begin{array}{l}\overline{\mathrm{R}}^{2}= \\
\quad \text { Standard Error } \\
\quad \text { of Estimate: }\end{array}$ & .41 & .35 \\
\hline $\mathrm{SSE}=$ & 118306.67 & 3016.02 \\
\hline $\mathrm{SSR}=$ & 144223.57 & 4377.07 \\
\hline $\mathrm{F} \quad=$ & 9.55 & 7.68 \\
\hline $\mathrm{n}=$ & 86 & 86 \\
\hline
\end{tabular}
(Weighted Least Squares)

Note: $\mathrm{T}$ statistics are in parentheses. All of the values for both dependent variables were between 0 and $1 . R^{2} s, F$ statistics, and SSE and SSR estimates may not have the usual interpretations when using weighted log-odds regressions and are reported here only for illustrative purposes. Similar results were otained using other specifications, such as In (WPREM), and are available from the authors.

* Statistically significant at the .10 level: ** at the .05 level; *** at the .01 level 
and unemployment in the plant's SMSA (UE) are both positively and significantly related to grievances; where unemployment is higher, the costs associated with finding alternative work rise, and the costs of using the alternatives to the grievance process (which increase the probability of dismissal) therefore rise as well. The elasticities for these labor market variables are large (1.0 for WPREM, 1.01 for UE, and .16 for LAIDOFF), suggesting that these relationships are empirically important. For example, a one percent increase in the wage premium is associated with a one percent increase in grievance levels. These measures are essentially cross-price elasticities that examine the effects of price changes for substitutes on the demand for some alternative.

The variable identifying assembly plants (ASSMBLY) suggests that workers at those plants use the grievance procedure more extensively than those at other plants (partsmanufacturing plants), possibly because they have more to lose from unemployment given their greater wage premiums. The variable identifying the extent of cooperative relations between plant management and labor (COOP) has the predicted signs but fails to achieve conventional levels of significance. ${ }^{11}$ The variables for seniority (SEN) and skill (SKL) also fail to achieve significant relationships.

The results for equation (2) are virtually identical to those for equation (1). Bearing in mind the limitations noted above concerning the dependent variable, the results suggest that a greater proportion of workplace problems are addressed through the grievance procedure when the costs associated with using alternative methods increase. Because of the possibility that the component variables in the denominator might be determined simultaneously with

${ }^{11}$ A reciprocal specification of the variable$1 /$ coop-yields a coefficient significant at the $10 \%$ level, suggesting that cooperative relations may have a nonlinear relationship with grievance rates. We also examined other specifications of the equation, such as one in which absenteeism and discipline were included as separate R.H.S. variables, and observed no important effects on the results. These results are available on request. the grievance level, we examined this result further with a two-stage least squares regression to generate an instrumental variable for the denominator. The results, available on request, are virtually identical to those in Table 2. Separate F tests suggest that the labor market variables (WPREM, ASSMBLY, LAIDOFF, and UE) when taken together have a significant relationship with both dependent variables at the one percent level. The conflict control variables (SEN, SKL, and COOP) are jointly significant at the $10 \%$ level. (We recognize that several variables capture aspects of both labor markets and conflict, which may confound this test.)

The elasticities for the labor market variables in equation (2) provide a means for examining the substitution across problemsolving mechanisms that results from changes in their relative costs. These elasticities represent the change in the proportion of problems dealt with through the grievance process that is associated with a change in the relative price of alternatives. They are .83 for WPREM, .74 for UE, and .13 for LAIDOFF. Thus, for example, the results suggest that doubling the wage premium will increase the proportion of problems addressed through grievances by $83 \% .^{12}$

\section{Conclusions}

Despite the fact that grievance processes are among the most important aspects of employment relations and grievance rates are a standard measure of the state of employee relations, the previous literature has produced few, if any, sustainable explanations about the determinants of grievance activity. In particular, no previous research has looked at factors outside the firm, such as labor market conditions, to explain grievance rates. We have pro-

\footnotetext{
${ }^{12}$ Where $e=d\left(Q_{g} / Q_{a}\right) / Q_{g} / Q_{a} / d\left(P_{g} / P_{a}\right) / P_{g} / P_{a}$. Because the equation is in a log-odds form, the elasticity is computed as (GRATE* - GRATE)/GRATE, where GRATE* $=e^{d} / 1+e^{d}$ and $d=($ lnGRATE $/ 1-$ GRATE $)+$ (bWPREM(.01)WPREM). The elasticities also suggest that the production function for equity that relates grievances and alternative mechanisms to conflict resolution may be of the Cobb-Douglas form, given that elasticities of substitution under that function are unitary.
} 
posed a simple model in which workers choose the grievance process from among a set of alternative methods for addressing workplace conflicts, and the extent to which the grievance process is used depends on the relative costs of the various methods.

Consistent with our model, our analysis of data from a large, multi-plant manufacturing firm has shown that the greater the advantages of workers' current jobs, as indicated by wage premiums or high levels of unemployment in the outside market, the greater their use of grievance procedures-presumably reflecting the greater costs of using alternative methods to resolve problems (such as shirking or absenteeism), which generally lead to at least an increased risk of job loss. One way to think of this result is in terms of a demand by workers for the use of voice mechanisms like grievance procedures that varies with the price of using such mechanisms. These results also suggest an extension of the basic efficiency wage argument. The potential gains associated with a wage premium may include greater use of institutionalized grievance procedures and a reduction in the use of alternatives such as quitting, absenteeism, and shirking, alternatives that may be more costly for employers.

\section{APPENDIX}

Following is a formal version of the model used in this study, in which the extent to which workers use grievance procedures is hypothesized to vary directly with the size of their wage premiums and with the level of unemployment in the outside labor market.

$$
\operatorname{Min} C=a P_{g}+b P_{a}
$$

where $P_{g}$ is the price of using the grievance procedure, $P_{a}$ is the price of using alternative procedures, and $P_{g}, P_{a}>0$.

Subject to a given level of inequity that must be addressed, $Q_{0}=Q(g, a)$, the first-order condition for minimizing $C$ requires solving the Lagrangian:

$$
Z=a P_{g}+b P_{a}+u\left[Q_{0}-Q(g, a)\right]
$$

and the following first-order conditions:

$$
\begin{aligned}
& Z_{u}=Q_{o}-Q(g, a)=0 \\
& Z_{g}=P_{g}-u Q_{g}=0 \\
& Z_{a}=P_{a}-u Q_{a}=0 .
\end{aligned}
$$

Because the form of the production function is unknown and may not be strictly quasi-convex, the second-order condition requires the following negative bordered Hessian:

(A3) $H=u\left(Q_{a a} Q_{g}^{2}-2 Q_{a g} Q_{a} Q_{b}+Q_{g g} Q_{a}^{2}\right)<0$

where $\mathrm{u}=$ marginal cost of production or $=\partial P_{a} / P_{g}$ $=\partial Q_{a} / Q_{g}$. The outcome of the optimization should yield:

$$
\begin{aligned}
& Q_{g}, Q_{a}>0 \text { and } \\
& \partial Q_{g} / \partial P_{a}>0, \partial^{2} Q_{g} / \partial^{2} P_{a}<0 \\
& \partial Q_{g} / \partial P_{g}<0, \partial^{2} Q_{g} / \partial^{2} P_{g}<0 .
\end{aligned}
$$

Testing the hypothesis described above will amount to testing whether $\partial Q_{b} / \partial P_{a}>0$.

\section{REFERENCES}

Adams, J. S. 1963. "Toward an Understanding of Inequity." Journal of Abnormal and Social Psychology, Vol. 67, No. 5, pp. 422-36.

Akerlof, George A. 1982. "Labor Contracts as Partial Gift Exchange.” Quarterly Journal of Economics, Vol. 97, No. 1, pp. 543-69.

1984. "Gift Exchange and Efficiency Wage

Theory: Four Views." American Economic Review

Proceedings, Vol. 74, No. 2, pp. 79-83.

Akerlof, George A., and Janet L. Yellen. 1986. Efficiency Wage Models of the Labor Market. Cambridge: Cambridge University Press.

Amemiya, Takeshi, and Frederick Nold. 1975. "A
Modified Logit Model." Review of Economics and Statistics, Vol. 57, No. 2, pp. 255-57.

Ash, P. 1970. "The Parties to the Grievance." Personnel Psychology, Vol. 23, No. 1, pp. 13-37.

Berkowitz, Leonard, and Elaine Walster, eds. 1976. Equity Theory: Toward a General Theory of Social Interaction. New York: Academic Press.

Blauner, Robert. 1964. Alienation and Freedom. Chicago: University of Chicago Press.

Borjas, George J. 1979. "Job Satisfaction, Wages, and Unions." Journal of Human Resources, Vol. 14, No. 1, pp. $21-40$.

Brett, Jeanne M., and Stephen B. Goldberg. 1979. "Wildcat Strikes in Bituminous Coal Mining." 
Industrial and Labor Relations Review, Vol. 32, No. 4, pp. $465-83$.

Cappelli, Peter, and Peter S. Sherer. 1988. "Market Wages and Satisfaction: An Airline Study." Industrial Relations, Vol. 29, No. 1, pp. 1-27.

1991. "The Missing Role of Context in OB:

The Need for a Meso-Level Approach." In L. L. Cummings and Barry M. Staw, eds., Research in Organizational Behavior. Greenwich, Conn.: JAI Press, pp. 55-110.

Dalton, Dan R., and William D. Todor. 1981. "Win, Lose, Draw: The Grievance Process in Practice." Personnel Administrator, Vol. 26, No. 3, pp. 25-29.

1979. "Manifest Needs of Stewards: Propensity to File a Grievance." Journal of Applied Psychology, Vol. 64, No. 6, pp. 654-59.

Elkouri, Frank, and Edna Asper Elkouri. 1985. How Arbitration Works. Washington, D.C.: BNA.

Freeman, Richard B. 1980. "The Exit-Voice Tradeoff in the Labor Market: Unionism, Job Tenure, Quits, and Separations." Quarterly Journal of Economics, Vol. 94, No. 3, pp. 643-73.

Gordon, Michael E., and Sandra J. Miller. 1984. "Grievances: A Review of Research and Practice." Personnel Psychology, Vol. 37, No. 2, pp. 117-46.

Hirschman, Albert O. 1970. Exit, Voice, and Loyalty: Responses to Decline in Firms, Organizations, and States. Cambridge, Mass.: Harvard University Press.

Ichniowski, Casey. 1986. "The Effects of Grievance Activity on Productivity." Industrial and Labor Relations Review, Vol. 40, No. 1, pp. 75-89.

Ichniowski, Casey, and David Lewin. 1987. "Grievance Procedures and Firm Performance." In Morris M. Kleiner et al., eds., Human Resources and the Performance of the Firm. Madison, Wis.: Industrial Relations Research Association.

Katz, Harry, Thomas A. Kochan, and Kenneth Gobeille. 1983. "Industrial Relations Performance, Economic Performance, and the Effects of Quality of Working Life Efforts: An Inter-Plant Analysis." Industrial and Labor Relations Review, Vol. 37, No. 1, pp. 3-17.

Katz, Harry, Thomas A. Kochan, and Jeffrey $\mathrm{H}$. Keefe. 1987. "Industrial Relations and Productivity in the U.S. Automobile Industry." Brookings Papers on Economic Activity: Special Issue on Microeconomics. Washington, D.C.: Brookings Institution.

Kissler, G. D. 1977. "Grievance Activity and Union Membership: A Study of Government Employees." Journal of Applied Psychology, Vol. 62, No. 4, pp. 459-62.

Kleiner, Morris M., Gerald Nickelsburg, and Adam Pilarski. 1989. "Monitoring, Grievances, and Plant Performance." Paper presented to the National Bureau of Economic Research Summer Workshop in Labor Studies, July.

Krueger, Alan, and Lawrence H. Summers. 1988. "Reflections on the Inter-Industry Wage Structure." In Kevin Lang and Jonathan Leonard, eds.,
Unemployment and the Structure of Labor Markets. Oxford: Blackwell.

Kuhn, James W. 1961. Bargaining and Grievance Settlement. New York: Columbia University Press.

Leonard, Jonathan S. 1984. "Carrots and Sticks: Pay, Supervision, and Turnover." Journal of Labor Economics, Vol. 5, No. 4, pp. 136-52.

Lewin, David. 1984. "Theoretical Perspectives on the Modern Grievance Procedure." In Joseph D. Reid, ed., New Approaches to Labor Unions, Supplement 2 of Ronald G. Ehrenberg, ed., Research in Labor Economics. Greenwich, Conn.: JAI Press, pp. 127-47.

McKelvey, Jean, ed. 1977. The Duty of Fair Representation. Ithaca, N.Y.: ILR Press.

Mobley, William H., R. W. Griffith, H. H. Hand, and B. M. Meglino. 1979. "Review and Conceptual Analysis of the Employee Turnover Process." Psychological Bulletin, Vol. 86, No. 3, pp. 493-522.

Murchinsky, Paul M., and Mounawar A. Maassarani. 1980. "Work Environment Effects in Public Sector Grievances.” Personnel Psychology, Vol. 33, No. 3, pp. 403-14.

Norsworthy, J. R., and Craig Zabala. 1985. "Worker Attitudes, Worker Behavior, and Productivity in the U.S. Automobile Industry, 1959-1976." Industrial and Labor Relations Review, Vol. 38, No. 4, pp. 544-57.

Peach, David A., and E. Robert Livernash. 1974. Grievance Initiation and Resolution: A Study in Basic Steel. Cambridge, Mass.: Harvard University Press.

Porter, L., and R. Steers. 1973. "Organizational, Work and Personal Factors in Employee Turnover and Absenteeism." Psychological Bulletin, Vol. 80, No. 1, pp. 151-76.

Salvendy, Gavriel. 1976. "Effects of Equitable and Inequitable Financial Compensation on Operators' Productivity, Satisfaction, and Motivation." International Journal of Production Research, Vol. 14, No. 1, pp. 305-10.

Shapiro, Carl, and Joseph E. Stiglitz. 1984. "Equilibrium Unemployment as a Worker Discipline Device." American Economic Review, Vol. 74, No. 3, pp. 433-44.

Smith, Adam. 1776. An Inquiry into the Nature and Causes of the Wealth of Nations. Dublin: Whitestone.

Smith, P. C., L. M. Kendall, and C. L. Hulin. 1969. The Measurement of Satisfaction in Work and Retirement. Chicago: Rand-McNally.

Staw, Barry M., Nancy Bell, and Jill Clausen. 1986. "The Dispositional Approach to Job Attitudes: A Lifetime Longitudinal Test." Administrative Science Quarterly, Vol. 13, No. 1, pp. 56-77.

Stiglitz, Joseph E. 1986. Theories of Wage Rigidity. Cambridge, Mass.: NBER Reprint No. 726.

Sulkin, H. A., and R. W. Pranis. 1967. "Comparison of Grievants and Non-Grievants in a Heavy Machinery Company." Personnel Psychology, Vol. 30, No. 2, pp. 111-19.

Weick, Karl E. 1979. The Social Psychology of Organizing. Reading, Mass.: Addison-Wesley. 